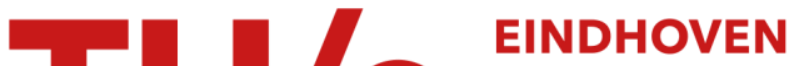 UNIVERSITY OF TECHNOLOGY
}

\section{Conductivity enhancement of binder-based graphene inks by photonic annealing and subsequent compression rolling}

\section{Citation for published version (APA):}

Arapov, K., Bex, G., Hendriks, R., Rubingh, E., Abbel, R., de With, G., \& Friedrich, H. (2016). Conductivity enhancement of binder-based graphene inks by photonic annealing and subsequent compression rolling. Advanced Engineering Materials, 18(7), 1234-1239. https://doi.org/10.1002/adem.201500646

DOI:

10.1002/adem.201500646

Document status and date:

Published: 01/01/2016

\section{Document Version:}

Publisher's PDF, also known as Version of Record (includes final page, issue and volume numbers)

\section{Please check the document version of this publication:}

- A submitted manuscript is the version of the article upon submission and before peer-review. There can be important differences between the submitted version and the official published version of record. People interested in the research are advised to contact the author for the final version of the publication, or visit the $\mathrm{DOI}$ to the publisher's website.

- The final author version and the galley proof are versions of the publication after peer review.

- The final published version features the final layout of the paper including the volume, issue and page numbers.

Link to publication

\section{General rights}

Copyright and moral rights for the publications made accessible in the public portal are retained by the authors and/or other copyright owners and it is a condition of accessing publications that users recognise and abide by the legal requirements associated with these rights.

- Users may download and print one copy of any publication from the public portal for the purpose of private study or research.

- You may not further distribute the material or use it for any profit-making activity or commercial gain

- You may freely distribute the URL identifying the publication in the public portal.

If the publication is distributed under the terms of Article 25fa of the Dutch Copyright Act, indicated by the "Taverne" license above, please follow below link for the End User Agreement:

www.tue.nl/taverne

Take down policy

If you believe that this document breaches copyright please contact us at:

openaccess@tue.nl

providing details and we will investigate your claim. 


\title{
Conductivity Enhancement of Binder-Based Graphene Inks by Photonic Annealing and Subsequent Compression Rolling**
}

\author{
By Kirill Arapov, Guy Bex, Rob Hendriks, Eric Rubingh, Robert Abbel, Gijsbertus de With \\ and Heiner Friedrich*
}

This paper describes a combination of photonic annealing and compression rolling to improve the conductive properties of printed binder-based graphene inks. High-density light pulses result in temperatures up to $500^{\circ} \mathrm{C}$ that along with a decrease of resistivity lead to layer expansion. The structural integrity of the printed layers is restored using compression rolling resulting in smooth, dense, and highly conductive graphene films. The layers exhibit a sheet resistance of less than $1.4 \Omega \square^{-1}$ normalized to $25 \mu \mathrm{m}$ thickness. The proposed approach can potentially be used in a roll-toroll manner with common substrates, such as polyethylene terephthalate (PET), polyethylene naphthalate (PEN), and paper, paving thereby the road toward high-volume graphene-printed electronics.

\section{Introduction}

Solution-processed conductive inks are important materials for the manufacturing of low-cost high-throughput printed electronics such as displays, ${ }^{[1-3]}$ organic light-emitting diodes (OLEDs) ${ }^{[4,5]}$ roll-to-roll (R2R) printed solar cells, ${ }^{[6-10]}$ and radio frequency identification tags. ${ }^{[11-13]}$ Even though the field of printable conductors is still mainly focused on metalbased (Ag, Cu, $\approx 50 \mathrm{~m} \Omega \square^{-1}$ at $25 \mu \mathrm{m}$ thickness) ${ }^{[13,14]}$ inks and

[*] Dr. H. Friedrich, Dr. K. Arapov, Prof. G. de With Laboratory of Materials and Interface Chemistry, Department of Chemical Engineering and Chemistry, Eindhoven University of Technology, De Zaale, 5612AJ Eindhoven, The Netherlands E-mail: h.friedrich@tue.nl

G. Bex, E. Rubingh, Dr. R. Abbel

Holst Centre - TNO, High Tech Campus 31, 5656AE Eindhoven, The Netherlands

R. Hendriks

NovaCentrix, Inc., 400 Parker Drive, Austin, Texas 78728, USA

[**] The research leading to these results has received funding from the European Union Seventh Framework Program (FP7-MCITN) under grant agreement No. 264710 and under grant agreement $n^{\circ} 604391$ Graphene Flagship. The authors would like to thank the Directorate-General for Science, Research and Development of the European Commission for support of the research.
PEDOT:PSS dispersions $\left(\approx 50 \Omega \square^{-1}\right)$, [15] graphene-based conductive inks are gaining attention both from science ${ }^{[16-24]}$ and technology. ${ }^{[25]}$

Unfortunately, the conductive properties of graphene inks and printed structures thereof are still far from being a replacement for silver and copper inks. To increase the conductivity of final structures, post-processing methods, such as long-time thermal annealing ${ }^{[19,20,24]}$ or compression rolling, ${ }^{[23,26]}$ can be employed, thus, increasing the application potential of graphene-based printable conductors. In particular, thermal annealing is known to be a very efficient method to improve the conductivity of graphene, ${ }^{[19,20,24,27]}$ as it results in desorption of the surface contaminants and degradation of binders and other ink components, e.g., rheology modifiers. However, the commonly used substrates, such as polyethylene terephthalate (PET), polyethylene naphthalate (PEN), and paper, do not tolerate long-time treatment at temperatures above $150{ }^{\circ} \mathrm{C}$, thus, preventing conventional thermal annealing approaches. The second method, compression rolling, can also significantly decrease the sheet resistance of printed graphene by pressing graphene sheets together, thus improving interlayer contacts. However, at the moment the best results have been reported for binder-free graphene ink formulations, where graphene flakes are not immobilized in a polymer network. The presence of a binder with a glass transition point above room temperature may lower the particle mobility even under high force applied, obstruct sheet-to-sheet interactions, and thereby render the application 
of compression rolling inefficient. Nevertheless, taking into account the two main aspects of performance an ink should provide, i.e., good printability with high printing definition and sufficiently low sheet resistance, e.g., less than $5 \Omega \square^{-1}$, it becomes clear from previous works ${ }^{[16,18-20,22,25,26,28-30]}$ that the use of a binder, surfactant, or rheology modifier is necessary. These rheological modifications should be compatible with the commonly used R2R-friendly flexible substrates and comply with already existing high-speed technologies. Hence, conductivity enhancing post-processing methods should be fast and applicable to common substrates.

Application of compression rolling results in the lowest sheet resistance reported, if used with binder-free inks. ${ }^{[23,26]}$ However, we believe that this method can also be efficiently applied to binder-based formulations combined with binder degradation. For instance, short-time high-temperature selective heating of graphene composite layers may result in removal of residual solvent and water and degradation of the binder when heated above its decomposition temperature in air. Such an annealing of graphene sheets only for short time intervals is also safe for the substrate (even PET and PEN), as the heating is only local and indirect. These methods include Joule heating, ${ }^{[31]}$ microwave irradiation, ${ }^{[12]}$ infra-red heating, ${ }^{[32]}$ and photonic flash annealing. ${ }^{[6,33-35]}$ The latter is a contactless, highly controllable method compatible with highspeed $R 2 R$ processing and, since it is based on the light absorption, holds great promise for graphene applications.

Considering all of the above, there is at present no general approach combining ink formulation based on graphene only as a conductive filler and post-treatment methods, that provides high printing definition, low sheet resistance $\left(<5 \Omega \square^{-1}\right)$, and compatibility with commonly used substrates. The development of such an approach, that is able to satisfy and balance all requirements, will be a significant step toward the industrial realization of printable graphene conductors.

In this paper, we focus on the post-processing of a binderbased graphene screen printing paste comprising photonic annealing and subsequent compression rolling to achieve a low sheet resistance for printed layers. We show the influence of the photonic annealing parameters, such as light flux output energies, on the conductive properties and the morphology of printed layers. Subsequently, we discuss the effect of compression rolling, in particular the changes in morphology and conductivity. The combination of these two methods is, we believe, an efficient approach to improve the conductance of binder-based graphene inks with post-processing.

\section{Results and Discussion}

For ink formulation, we used our recently published approach that involves gelation of highly concentrated graphene dispersions by
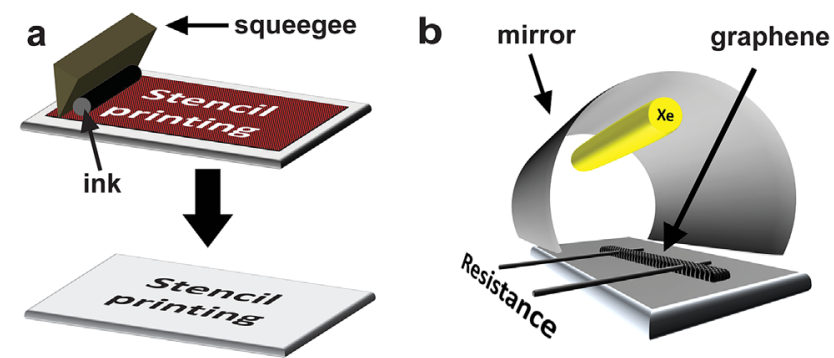

Fig. 1. Stencil printing and photonic annealing. (a) Scheme of stencil printing; (b) scheme of photonic annealing with a curved mirror of proprietary shape, xenon lamp, substrate with a graphene line printed over the electrodes.

mild heating followed by solvent exchange. ${ }^{[36]}$ The resulting graphene screen printing paste has shown high printing definition and good conductive properties. To investigate the influence of post-processing methods on the morphology and conductive properties of the graphene conductors, a line was stencil printed (Figure 1a) across resistivity/temperature probes $^{[33]}$ (Figure $1 b$ ). Details on the setup and it is operating principle can be found in Abbel et al. ${ }^{[33]}$ Here, stencil printing is used as a simplified version of screen printing enabling fast sample preparation with fair printing definition. After predrying at $100^{\circ} \mathrm{C}$ in an oven for $5 \mathrm{~min}$, the sample was subjected to a series of consecutive light pulse bursts with $5 \mathrm{~s}$ intervals between each burst. Each light burst consists of 10 light pulses consecutively fired with a frequency of $1 \mathrm{~Hz}$ and corresponds to energy densities of 1.60, 1.92, 2.29, 2.67, and $3.08 \mathrm{~J} \mathrm{~cm}^{-2}$ (for a single pulse), respectively, measured by a built-in bolometer. In Figure 2a, each maximum (temperature plot) or minimum (relative resistance plot) corresponds to a single light pulse. The light is adsorbed by the graphene, the energy converted to heat, and a decrease in resistance is observed due to the negative thermal coefficient. ${ }^{[32,37]}$ In addition, heating promotes fast desorption of surface adsorbates, e.g., solvent molecules, lowering the resistance further. Since after the end of each pulse, the sample cools down to room temperature, the resistance increases again. However, it does not reach its original value, but stabilizes at a resistance which is about $10 \%$ lower than before the pulse

\section{a}
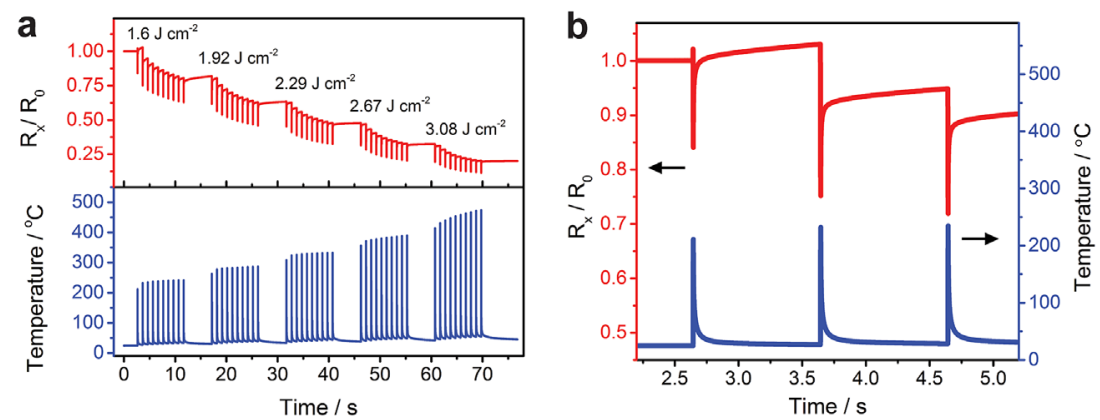

Fig. 2. Photonic annealing. (a) Light pulse bursts with 10 pulses in each of 1.60, 1.92, 2.29, 2.67, and $3.08 \mathrm{~J} \mathrm{~cm}^{-2}$ (from left to right) and $5 \mathrm{~s}$ intervals between each burst, corresponding to a flash lamp bias of 280, $300,320,340$, and $360 \mathrm{~V}$, with a pulse duration of $2 \mathrm{~ms}$, firing frequency $1 \mathrm{~Hz}$; (b) first, second, and third pulses at $1.60 \mathrm{~J} \mathrm{~cm}^{-2}$ with a duration of $2 \mathrm{~ms}$ and firing frequency $1 \mathrm{~Hz}$. In the relative resistance graph (Figure $2 b$, upper graph) for the first pulse, a spike, corresponding to layer expansion, is clearly present. 
(according to our measurements the contact resistance between probes does not exceed $5 \Omega$, and, thus could be neglected here). Hence, firing of several consecutive pulses leads to an overall decrease of the sample resistance. Figure $2 \mathrm{a}$ shows clearly that with an increase in photon flux the resistance decreases further, reaching the lowest values after photonic treatment with pulses of $3.08 \mathrm{~J} \mathrm{~cm}^{-2}$. It is interesting to note that this photon flux results in sample heating to above $450{ }^{\circ} \mathrm{C}$ for time intervals of less than $5 \mathrm{~ms}$. Reaching this temperature even for a short time interval is apparently sufficient to desorb the solvent, and, at least partially, degrade the binder, thus improving the overall conductive properties of the printed layers.

The resistance curve for the first pulse shows a spike (Figure 2b) of approximately $2-3 \%$ followed by a steep decrease, while all consecutive pulses result in no spikes (Figure 2b).

From the photonic flux energy sweep (Figure 2a), we can see that a high flux quickly and effectively lowers the resistance of the stencil-printed graphene line by about five times reaching $40 \Omega \square^{-1}$ for an approximately $6 \mu \mathrm{m}$ thick layer (thickness before photonic annealing). Additionally, it can be inferred that the light pulses with higher energy densities result in a higher decrease of resistivity, suggesting that an energy density of more than $3 \mathrm{~J} \mathrm{~cm}^{-2}$ should be used. The process possibly can be further optimized by varying pulse sequence combined with pulse energy.

Irradiating the sample with 20 pulses of $3.35 \mathrm{~J} \mathrm{~cm}^{-2}$, as presented in Figure 3, results in a decrease of resistance down to $17 \%$ of the initial value, reaching less than $40 \Omega \square^{-1}$ for an approximately $6 \mu \mathrm{m}$ thick line (thickness before photonic annealing) in just $20 \mathrm{~s}$. With the passage of subsequent pulses, temperatures of up to $500^{\circ} \mathrm{C}$ were reached for these settings. Consistent with the experiments using $1.60 \mathrm{~J} \mathrm{~cm}^{-2}$, we observed a drastic increase in resistivity, in this case up to $40 \%$ of the initial value for the first pulse. This, again, suggests ongoing thermally activated structural changes within the printed layer.

Comparison of the results given in Figure $2 \mathrm{a}$ and 3 for both experiments shows a similar exponential decay of the resistance during heating and saturating after a few pulses. The fact that no plateau is reached in Figure $2 \mathrm{a}$ for the first pulse sequence, i.e., the lowest energy density of $1.60 \mathrm{~J} \mathrm{~cm}^{-2}$, indicates that using a higher energy density could decrease the resistance even further, as indeed observed for higher energy density sequences. The absolute values of relative resistance in these two data sets have to differ as the applied energy densities are different, that is, 1.60 and $3.35 \mathrm{~J} \mathrm{~cm}^{-2}$, respectively. To investigate the reason for such an increase, we performed both surface and cross-sectional scanning electron microscopy (SEM)

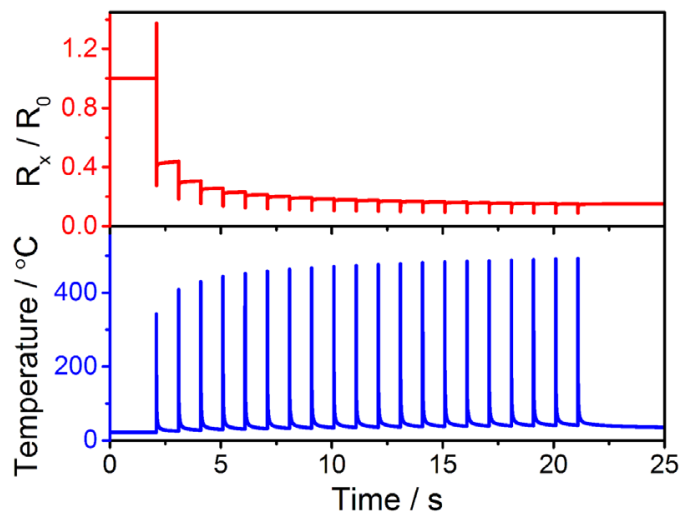

Fig. 3. Resistivity and temperature profiles as function of the flash photonic annealing time with $3.35 \mathrm{~J} \mathrm{~cm}^{-2}$ pulses of duration $2 \mathrm{~ms}$ and with firing frequency $1 \mathrm{~Hz}$.

analysis of dried samples (Figure $4 \mathrm{a}$ and $\mathrm{d}$ ) and samples subsequently subjected to photonic annealing (Figure $4 \mathrm{~b}$ and e). We observed that samples subjected to photonic annealing have an increased layer thickness. In particular, crosssectional SEM imaging of photonically annealed layers shows a change from a dense, tile-like stacking of graphene sheets toward a more porous morphology (Figure $4 \mathrm{a}$ and b). Tentatively, we attribute this change in morphology to the quick conversion of solid or liquid components to the gas phase with a significant increase of pressure between the graphene layers, as observed during thermal expansion of graphite intercalation compounds. ${ }^{[27]}$ The fact that a spikelike increase in resistivity is only noted in the first pulse and never in subsequent pulses indicates probably that most of the desorbing and/or degradation processes are completed after the first rapid heating. $100^{\circ} \mathrm{C}$
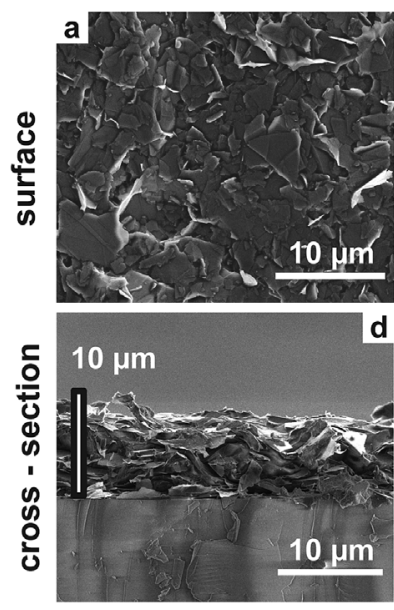

Fig. 4. Scanning electron micrographs of the surface (upper row) and a cross-section (lower row) of $(a, d) a$ stencil-printed line dried at $100^{\circ} \mathrm{C}$ for $5 \mathrm{~min},(b, e)$ a line dried at $100^{\circ} \mathrm{C}$ for $5 \mathrm{~min}$ and subjected to photonic annealing $\left(3.35 \mathrm{~J} \mathrm{~cm}^{-2}, 2 \mathrm{~ms}, 1 \mathrm{~Hz}, 20\right.$ pulses), and $(c, f)$ a line dried at $100^{\circ} \mathrm{C}$ for $5 \mathrm{~min}$, subjected to photonic annealing $\left(3.35 \mathrm{~J} \mathrm{~cm}^{-2}, 2 \mathrm{~ms}, 1 \mathrm{~Hz}, 20\right.$ pulses), and compression rolling. For the cross-sectional SEM images, the vertical scale bars are given only for comparative purposes, as the layer cross-sections appear to be thicker due to a charging effect. 


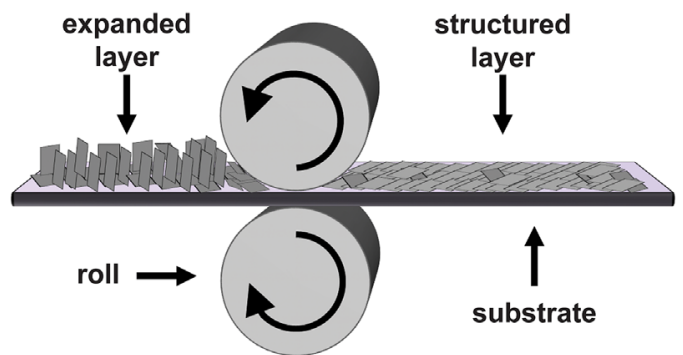

Fig. 5. Restructuring of an expanded graphene layer by compression rolling.

While dried graphene layers cannot be pulled off with a sticky-tape, the layers subjected to photonic annealing show significant material transfer with such a test, suggesting poor layer adhesion and cohesion. This, along with the porous morphology (Figure $4 \mathrm{~b}$ and e), is a clear indication that photonic annealing causes a loss of structural integrity, most likely related to degradation of the binder and a decrease in the number of contact points between the graphene sheets. Even though we observe a significantly improved conductance for photonically annealed graphene layers, deterioration of the mechanical properties decreases the application potential of photonic annealing without further modification and/or addition as the method of choice for high-performance graphene conductors.

Using binder-free suspensions, highly conductive and densely packed graphene films can be obtained by compression rolling ${ }^{[23,26]}$ (Figure 5). In this approach, two rotating rolls mechanically compress graphene sheets, forming strong attractive van der Waals bonds between them. Compression rolling regains the structural integrity, becoming comparable to that of a tiled, printed graphene layer and results in a very compact film with excellent mechanical, thermal, and electrical characteristics. ${ }^{[23,26]}$ We applied this approach to photonically annealed graphene layers. The resulting film, shown in Figure 4c, in comparison with the dried (Figure 4a) or dried and photonically annealed (Figure $4 \mathrm{~b}$ ) films, exhibits a smooth and uniform surface with almost indistinguishable graphene layers and a minor amount of imperfections. In the cross-sectional SEM micrograph (Figure 4f) it can be clearly seen that, comparing this image with that of a photonically

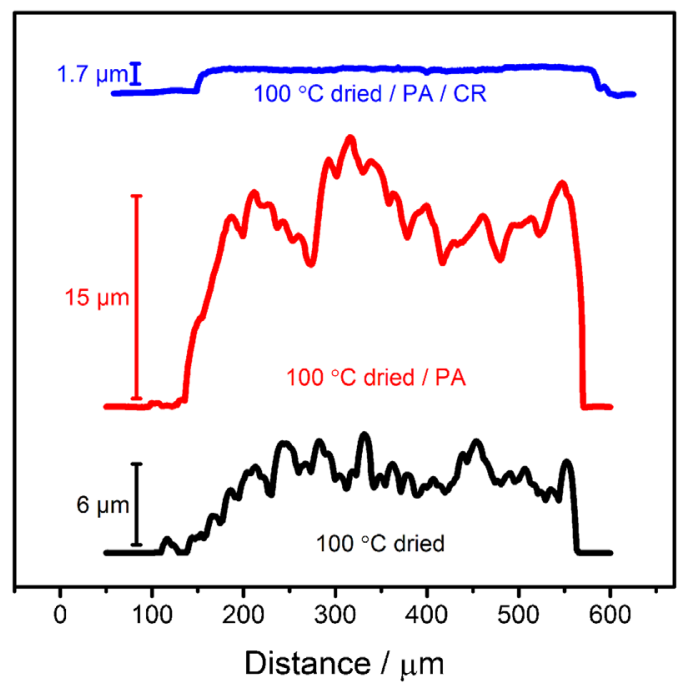

Fig. 6. Thickness variations for stencil-printed lines dried at $100{ }^{\circ} \mathrm{C}$ (bottom black), dried at $100^{\circ} \mathrm{C}$, and photonically annealed at $3.35 \mathrm{Jcm}^{-2}, 2 \mathrm{~ms}, 1 \mathrm{~Hz}, 20$ pulses $\left(100^{\circ} \mathrm{C} / \mathrm{PA}\right.$, middle red), and dried at $100^{\circ} \mathrm{C}$, photonically annealed at $3.35 \mathrm{~J} \mathrm{~cm}^{-2}$, $2 \mathrm{~ms}, 1 \mathrm{~Hz}, 20$ pulses and compression rolled $\left(100^{\circ} \mathrm{C} / \mathrm{PA} / \mathrm{CR}\right.$, top blue). The global average thickness values obtained by profilometry are somewhat smaller as compared to the local values observed by cross-sectional SEM due to charging effects.

annealed film (Figure 4e), compression rolling results in the restoration of a tile-like graphene sheet stacking constituting a compact film.

Using profilometry, we monitored the changes of graphene layer thickness after drying, photonic annealing, and compression rolling (Figure 6). Profiles shown in Figure 6 represent a single measurement, but measurements from different areas as well as from different samples follow the same trend. Thus, drying at $100^{\circ} \mathrm{C}$ for $5 \mathrm{~min}$ results in an approximately $6 \mu \mathrm{m}$ thick film using a $25 \mu \mathrm{m}$ thick stencil, that upon photonic annealing expands to a $15-17 \mu \mathrm{m}$ thick film. Further, we found that compression rolling of photonically annealed graphene layers produces an approximately $1.7 \mu \mathrm{m}$ thick film. Hence, the compression ratio, i.e., the ratio between the thickness before and after compression, is close to 10 . Additionally, in Figure 6 it can be clearly seen that compression rolling results in significant decrease of roughness in comparison with the roughness of the as-dried and photonically annealed layers (Table 1 ).

Table 1. Thickness, sheet resistance, and roughness $\left(R_{a}\right)$ of printed graphene layers after printing, drying at $100^{\circ} \mathrm{C}$, photonic annealing $\left(P A, 3.35 \mathrm{~J} \mathrm{~cm}{ }^{-2}, 2 \mathrm{~ms}, 1 \mathrm{~Hz}, 20\right.$ pulses), and compression rolling (CR).

\section{Conditions}

\begin{tabular}{|c|c|c|c|c|c|c|}
\hline \multirow[b]{2}{*}{ Parameter } & & & & & & \\
\hline & Printed/wet ${ }^{[\mathrm{a}]}$ & $100^{\circ} \mathrm{C}$ & $100^{\circ} \mathrm{C} / \mathrm{PA}$ & $100^{\circ} \mathrm{C} / \mathrm{PA} / \mathrm{CR}$ & Drying $^{[c]}$ & $\mathrm{CR}^{[\mathrm{c}]}$ \\
\hline Thickness, $[\mu \mathrm{m}]$ & $25^{[\mathrm{a}]}$ & 6 & 15 & 1.7 & 31.6 & 6 \\
\hline Resistance, $\left[\Omega \square^{-1}\right]$ & 2800 & 200 & 40 & 20 & 38 & 3.8 \\
\hline Resistance, $\left[\Omega \square^{-1}\right]$ normalized to $25 \mu \mathrm{m}$ & 2800 & 48 & $24^{[\mathrm{b}]}$ & 1.4 & 48 & 0.9 \\
\hline Roughness $\left(R_{\mathrm{a}}\right),[\mu \mathrm{m}]$ & - & 0.945 & 2 & 0.065 & - & - \\
\hline
\end{tabular}

${ }^{[\mathrm{a}]}$ Stencil thickness used is $25 \mu \mathrm{m} .{ }^{[\mathrm{b}]}$ Normalized for expanded layer. ${ }^{[c]}$ Data from X. Huang et al.; ${ }^{[23]}$ conditions unknown. 
The recovery of a tile-like dense graphene stacking, as shown in Figure $4 \mathrm{c}$ and $\mathrm{f}$, results in a decrease in sheet resistance by about $50 \%$ as compared to photonically annealed samples, reaching a value of approximately $20 \Omega \square^{-1}$ for a $1.7 \mu \mathrm{m}$ thick film (Table 1), corresponding to $1.4 \Omega \square^{-1}$ for a film thickness normalized to $25 \mu \mathrm{m}$. Extrapolation to $25 \mu \mathrm{m}$ or 1 mil thickness is common practice in the field ${ }^{[23,38]}$ but requires a linear dependence of conductivity with thickness which may not hold true for all processing conditions. In our case, up to the maximum achieved thicknesses of $12 \mu \mathrm{m}$ a linear dependence is observed, so that extrapolation to $1 \mathrm{mil}$ seems reasonable. The results shown here are comparable with the results of applying of compression rolling to binder-free printed layers as reported earlier ${ }^{[23]}$ (Table 1 ). However, the possibility to apply R2R processes to attain low sheet resistances for structures printed with high-definition inks that contain a binder, surfactant, and/or rheology modifier, balances the requirements for industrial realization of printed graphene conductors and provides a significant advantage over existing approaches.

\section{Conclusions}

In this paper, we demonstrated a post-processing approach, combining photonic annealing with (subsequent) compression rolling, to improve the conductive properties of samples printed using a binder-based graphene ink. The results reported here are comparable to those of earlier studies using compression rolling of a binder-free slurry of graphene flakes in N-methylpyrrolidone (NMP). ${ }^{[23,26]}$ The approach has been developed to balance the different requirements for printed electronics, such as good colloidal stability, printability, and high printing definition of the ink, post-treatments that are compatible with heat-sensitive substrates and good performance. Having printed a pattern of interest, we utilized photonic annealing to remove residual solvent and to degrade the binder by reaching temperatures up to $500{ }^{\circ} \mathrm{C}$ for short time intervals. This results in a decrease of resistivity by about five times from the initial value. We observed that such a drastic increase of temperature leads to the vaporization of adsorbed species and an interlayer pressure, resulting in layer expansion and poor structural integrity. Using compression rolling, we were able to restore this disrupted structural integrity of the printed layers, resulting in smooth, dense, and highly conductive graphene films. The layers exhibit a sheet resistance of less than $1.4 \Omega \square^{-1}$ when normalized to $25 \mu \mathrm{m}$ thickness. The approach proposed here is compatible with roll-to-roll (R2R) production lines and can potentially be used with transparent or non-absorbing substrates, such as polyethylene terephthalate (PET), polyethylene naphthalate (PEN), ultrathin glass, and special application paper, paving thereby the road toward graphene-printed electronics.

\section{Experimental Section}

For resistivity and temperature measurements, graphene ink $^{[36]}$ line was printed using a stainless steel $25 \mu \mathrm{m}$ thick stencil (Figure 1a) with dimensions $L \times W=3500 \times 500 \mu \mathrm{m}^{2}$. These lines were printed across measurement probes, the working principle of which was described previously by Abbel et al., ${ }^{[33]}$ on glass substrates with the printing direction perpendicular to the probes, as shown in Figure 1b. The distance between probes is $2500 \mu \mathrm{m}$. The resistivity and temperature measurements during photonic annealing were performed at $10 \mathrm{kHz}$.

The photonic annealing experiments were performed using a PulseForge 1300 (NovaCentrix, USA) apparatus with a xenon stroboscope lamp combined with a curved mirror, as shown in Figure 1b. To determine the optimal conditions for photonic annealing, we performed the pulse flashing at different output energy densities: 1.60, 1.92, 2.29, 2.67, and $3.08 \mathrm{~J} \mathrm{~cm}^{-2}$, measured by a built-in bolometer. These values correspond to a bias of $280,300,320,340$, and $360 \mathrm{~V}$, respectively, applied to the flash lamp with a pulse duration of $2 \mathrm{~ms}$. Final experiments were done using pulses of $3.35 \mathrm{~J} \mathrm{~cm}^{-2}$ using the same pulse duration with a repetition frequency of $1 \mathrm{~Hz}$.

Ex situ electrical resistance measurements were performed using a two-point probe Keithley 6517A resistance meter.

Compression rolling was performed using a Goldsmith BK-0090 stainless steel $57 \mathrm{~mm}$ roll (Goldsmith, China) at a speed of $10 \mathrm{~mm} \mathrm{~s}^{-1}$. The sample was sandwiched between two $5 \mathrm{~mm}$ thick polycarbonate (PC) foils to prevent contact between the graphene-printed layer and the rolls. From the displacement of the rolls $(\approx 200 \mu \mathrm{m})$ and the bulk modulus of the PC, we estimated the pressure to be less than $55-65 \mathrm{~N} \mathrm{~mm}^{-2}$.

Scanning electron microscopy was performed using FEI Quanta 3D FEG (field emission gun) microscope (FEI, USA) operated at $1 \mathrm{kV}$ accelerating voltage. Sample cross-sections were prepared by splitting of glass substrates that were orthogonally scored on the opposite side with respect to printed patterns. Multiple samples have been investigated and representative images of the surfaces and cross-sections of samples are shown in Figure 4.

Cross-section profiles were measured using a Veeco 150 Dektak profilometer (Bruker, USA) with a stylus radius of $12.5 \mu \mathrm{m}$, and a stylus force of $5 \mathrm{mg}$. No further profile enhancement has been applied. Multiple samples have been investigated and representative profiles are demonstrated in Figure 6.

Microscopic inspection of samples before and after measurements revealed no visible damage to the surface of the layers. The surface roughness is characterized by the arithmetic average of the absolute values of the profile height deviations from the mean line $\left(R_{\mathrm{a}}\right.$ value), recorded over a track of $300 \mu \mathrm{m}$.

Article first published online: March 29, 2016

Manuscript Revised: February 24, 2016

Manuscript Received: December 20, 2015 
[1] J. P. Coleman, A. T. Lynch, P. Madhukar, J. H. Wagenknecht, Sol. Energy Mater. Sol. Cells 1999, 56, 395.

[2] J. Daniel, A. C. Arias, W. Wong, R. Lujan, S. Ready, B. Krusor, R. Street, JJAP 2007, 46, 1363.

[3] H.-S. Koo, M. Chen, P.-C. Pan, Thin Solid Films 2006, 515, 896.

[4] A. Kamyshny, Open Appl. Phys. J. 2011, 4, 19.

[5] F. So, S. Harkema, S. Mennema, M. Barink, H. Rooms, J. S. Wilson, T. van Mol, D. Bollen, C. Adachi, Proc. SPIE 7415, Organic Light Emitting Materials and Devices XIII 2009, 7415, 74150T-74150T-74158.

[6] D. Angmo, T. T. Larsen-Olsen, M. Jørgensen, R. R. Søndergaard, F. C. Krebs, Adv. Energy Mater. 2013, 3, 172.

[7] T. M. Eggenhuisen, Y. Galagan, A. F. K. V. Biezemans, T. M. W. L. Slaats, W. P. Voorthuijzen, S. Kommeren, S. Shanmugam, J. P. Teunissen, A. Hadipour, W. J. H. Verhees, S. C. Veenstra, M. J. J. Coenen, J. Gilot, R. Andriessen, W. A. Groen, J. Mater. Chem. A 2015, 3, 7255.

[8] D. Kaduwal, H.-F. Schleiermacher, J. Schulz-Gericke, T. Kroyer, B. Zimmermann, U. Würfel, Sol. Energy Mater. Sol. Cells 2014, 124, 92.

[9] P. Kopola, T. Aernouts, R. Sliz, S. Guillerez, M. Ylikunnari, D. Cheyns, M. Välimäki, M. Tuomikoski, J. Hast, G. Jabbour, R. Myllylä, A. Maaninen, Sol. Energy Mater. Sol. Cells 2011, 95, 1344.

[10] J. S. Yu, I. Kim, J. S. Kim, J. Jo, T. T. Larsen-Olsen, R. R. Sondergaard, M. Hosel, D. Angmo, M. Jorgensen, F. C. Krebs, Nanoscale 2012, 4, 6032.

[11] G. A. Casula, G. Montisci, G. Mazzarella, IEEE Antennas Wirel. Propag. Lett. 2013, 12, 1400.

[12] J. Perelaer, B. J. de Gans, U. S. Schubert, Adv. Mater. 2006, 18, 2101.

[13] A. Rida, Y. Li, R. Vyas, M. M. Tentzeris, IEEE Antennas Propag. Mag. 2009, 51, 13.

[14] Y. Amin, Q. Chen, L.-R. Zheng, H. Tenhunen, Prog. Electromagn. Res. 2012, 130, 1.

[15] N. Kim, S. Kee, S. H. Lee, B. H. Lee, Y. H. Kahng, Y. R. Jo, B. J. Kim, K. Lee, Adv. Mater. 2014, 26, 2109.

[16] K. Arapov, R. Abbel, G. de With, H. Friedrich, Faraday Discuss. 2014, 173, 323.

[17] D. J. Finn, M. Lotya, G. Cunningham, R. J. Smith, D. McCloskey, J. F. Donegan, J. N. Coleman, J. Mater. Chem. C 2014, 2, 925.

[18] J. Li, F. Ye, S. Vaziri, M. Muhammed, M. C. Lemme, M. Ostling, Adv. Mater. 2013, 25, 3985.

[19] E. B. Secor, S. Lim, H. Zhang, C. D. Frisbie, L. F. Francis, M. C. Hersam, Adv. Mater. 2014, 26, 4533.
[20] E. B. Secor, P. L. Prabhumirashi, K. Puntambekar, M. L. Geier, M. C. Hersam, J. Phys. Chem. Lett. 2013, 4, 1347.

[21] K. Y. Shin, J. Y. Hong, J. Jang, Adv. Mater. 2011, 23, 2113.

[22] F. Torrisi, T. Hasan, W. Wu, Z. Sun, A. Lombardo, T. S. Kulmala, G. W. Hsieh, S. Jung, F. Bonaccorso, P. J. Paul, D. Chu, A. C. Ferrari, ACS Nano 2012, 6, 2992.

[23] X. Huang, T. Leng, X. Zhang, J. C. Chen, K. H. Chang, A. K. Geim, K. S. Novoselov, Z. Hu, Appl. Phys. Lett. 2015, 106, 203105.

[24] W. J. Hyun, E. B. Secor, M. C. Hersam, C. D. Frisbie, L. F. Francis, Adv. Mater. 2015, 27, 109.

[25] J. M. Crain, J. S. Lettow, I. A. Aksay, S. A. Korkut, K. S. Chiang, C.-H. Chen, R. K. Prud'homme, USA Patent \# 8,278,757, 2012.

[26] H. Malekpour, K. H. Chang, J. C. Chen, C. Y. Lu, D. L. Nika, K. S. Novoselov, A. A. Balandin, Nano Lett. 2014, 14, 5155.

[27] K. Arapov, A. Goryachev, G. de With, H. Friedrich, Synth. Met. 2015, 201, 67.

[28] L. T. Le, M. H. Ervin, H. Qiu, B. E. Fuchs, W. Y. Lee, Electrochem. Commun. 2011, 13, 355.

[29] L. T. Le, M. H. Ervin, H. Qiu, B. E. Fuchs, J. Zunino, W. Y. Lee, "Inkjet-printed graphene for flexible microsupercapacitors", presented at IEEE NANO 2011, Portland, OR, 15-18 Aug. 2011, 2011.

[30] W. Y. Lee, L. Le, D. Kong, M. H. Ervin, J. L. Zunino III, B. E. Fuchs, US Patent No. 9,165,721 B2, 2012.

[31] M. L. Allen, M. Aronniemi, T. Mattila, A. Alastalo, K. Ojanpera, M. Suhonen, H. Seppa, Nanotechnology 2008, 19, 175201.

[32] D. Kong, L. T. Le, Y. Li, J. L. Zunino, W. Lee, Langmuir 2012, 28, 13467.

[33] R. Abbel, T. van Lammeren, R. Hendriks, J. Ploegmakers, E. J. Rubingh, E. R. Meinders, W. A. Groen, MRS Commun. 2012, 2, 145.

[34] Y. Galagan, E. W. C. Coenen, R. Abbel, T. J. van Lammeren, S. Sabik, M. Barink, E. R. Meinders, R. Andriessen, P. W. M. Blom, Org. Electron. 2013, 14, 38.

[35] E. B. Secor, B. Y. Ahn, T. Z. Gao, J. A. Lewis, M. C. Hersam, Adv. Mater. 2015, 27, 6683.

[36] K. Arapov, E. Rubingh, R. Abbel, J. Laven, G. de With, H. Friedrich, Adv. Funct. Mater. 2016, 26, 586.

[37] H. Al-Mumen, F. Rao, W. Li, L. Dong, Micro Nano Lett. 2013, 8, 681 .

[38] X. Huang, T. Leng, M. Zhu, X. Zhang, J. Chen, K. Chang, M. Aqeeli, A. K. Geim, K. S. Novoselov, Z. Hu, Sci. Rep. 2015, 5, 18298 . 